\section{Regards sur l'économie allemande}

Bulletin économique du CIRAC

$94 \mid 2009$

Varia

\title{
Formation : priorité du gouvernement et de l'opinion
}

Isabelle Bourgeois

\section{(2) OpenEdition}

1 Journals

Édition électronique

URL : http://journals.openedition.org/rea/4004

DOI : $10.4000 /$ rea. 4004

ISBN : 978-2-8218-0884-3

ISSN : 1965-0787

\section{Éditeur}

CIRAC

Édition imprimée

Date de publication : 1 décembre 2009

Pagination : 40

ISSN : 1156-8992

Référence électronique

Isabelle Bourgeois, « Formation : priorité du gouvernement et de l'opinion », Regards sur l'économie allemande [En ligne], 94 | décembre 2009, mis en ligne le 01 décembre 2011, consulté le 15 septembre 2020. URL : http://journals.openedition.org/rea/4004

Ce document a été généré automatiquement le 15 septembre 2020

(C) CIRAC 


\title{
Formation : priorité du gouvernement et de l'opinion
}

\author{
Isabelle Bourgeois
}

1 En 2009, les dépenses d'éducation et de formation programmées par Bund, Länder et communes se sont élevées à 97,9 milliards $€$ - soit $4 \%$ de plus qu'en 2008 (Destatis,). S'y ajoutent les 8,7 milliards $€$ prévus pour la période 2009/2011 par la Loi d'investissement dans l'avenir (Zukunfstinvestitionsgesetz) adoptée dans le cadre des plans de relance. L'Allemagne se rapproche à grands pas de son objectif d'une part de $10 \%$ des dépenses de formation/recherche dans le PIB d'ici 2015. Car aux dépenses publiques s'ajoutent les dépenses privées : en 2006, date de la dernière collecte de données par Destatis, le total atteignait 144,8 milliards $€$. Avec la recherche, il s'élevait à 198,5 milliards $€$, soit 8,5\% du PIB. L'opinion semble convaincue elle aussi de l'importance stratégique de la formation: $90 \%$ des Allemands considèrent la hausse des dépenses en la matière comme la mesure la plus importante décidée par le nouveau gouvernement (ARDDeutschlandtrend, novembre 2009). (IB)

\section{INDEX}

Mots-clés : formation, éducation, politique éducative, dépenses, budget, finances publiques 